\title{
COVID-19 and Environmental Racism: Challenges and Recommendations
}

\author{
Anuli U. Njoku ${ }^{1 *}$ \\ ${ }^{1}$ Department of Public Health, College of Health and Human Services, Southern Connecticut State University, New Haven, CT, USA \\ *Corresponding Author: njokua3@southernct.edu
}

Citation: Njoku, A. U. (2021). COVID-19 and Environmental Racism: Challenges and Recommendations. European Journal of Environment and Public Health, 5(2), em0079. https://doi.org/10.21601/ejeph/10999

\begin{tabular}{|c|c|}
\hline ARTICLE INFO & ABSTRACT \\
\hline Received: 1 Jan. 2021 & COVID-19, the pandemic of highly contagious respiratory disease, presents a global public health emergency. \\
\hline Accepted: 25 Feb. 2021 & $\begin{array}{l}\text { Racial and ethnic minority groups in the USA are more likely to contract, be hospitalized with, and die from } \\
\text { COVID-19 versus whites, highlighting glaring health disparities. Injustices such as the persistent issue of police } \\
\text { brutality against Blacks in the USA, along with the racial disparities and inequities underscored by the COVID- } \\
19 \text { pandemic, have brought renewed global focus to issues of social justice in the USA. Moreover, there is a need } \\
\text { to examine how environmental racism intensifies the COVID-19 pandemic and illuminates racial inequities in } \\
\text { exposure to environmental pollutants. This article describes environmental racism and its impact on people of } \\
\text { color in the USA, critically examines how this practice elevates disease risk among racial and ethnic minorities } \\
\text { already susceptible to COVID-19, and proposes recommendations to tackle this pervasive issue. }\end{array}$ \\
\hline
\end{tabular}

Keywords: Coronavirus, COVID-19, health disparities, racism, environmental health, social determinants of health

\section{INTRODUCTION}

The world has been beset by "coronavirus disease 2019" (COVID-19), a pandemic of lower respiratory tract disease resulting in severe illness and potential death from pneumonia-like symptoms (Ameh et al., 2020; Sohrabi et al., 2020; Young et al., 2020; Zhu et al., 2020). The COVID-19 pandemic presents an international public health emergency (World Health Organization (WHO), 2021). The Centers for Disease Control and Prevention (CDC) has issued guidelines to prevent the spread of COVID-19, including getting a COVID19 vaccine when it is available. If unvaccinated, guidance to protect oneself and others include washing one's hands often, maintaining social distancing, avoiding close contact with people who are sick, wearing a mask in public settings and when around others who don't live in one's household, and staying home as much as possible. The CDC also advises people to seek medical care if they are sick with COVID-19 (CDC, 2021a). Persons at higher risk for COVID-19 include adults of any age with certain underlying medical conditions such as cancer, heart conditions, chronic kidney disease, chronic obstructive pulmonary disease (COPD), weakened immune system, Down syndrome, obesity, smoking, type 2 diabetes mellitus, pregnancy, and sickle cell disease (CDC, 2021b). In addition, United States (U.S.) data indicates that racial and ethnic minority groups are bearing a disproportionate burden of COVID-19-associated outcomes (CDC, 2021c). Black/African Americans, Hispanic/Latinx persons, and American Indian or Alaska Native, Non-Hispanic persons are more likely to contract, be hospitalized with, and die from COVID-19, when compared to non-Hispanic whites (CDC, 2021c).

While susceptibility to underlying health conditions such as hypertension, diabetes, high blood pressure and asthma play a role, systemic barriers such as likelihood of being uninsured, reduced access to affordable medical testing, diagnosis, and management; work-related exposures; food insecurity; and housing insecurity also likely contribute to racial and ethnic health disparities in COVID-19 (Egede and Walker, 2020; Hooper et al., 2020). Many of these underlying health conditions result from exposure to environmental toxins. Thus, the known risk factors for COVID-19 complications need to be examined within the context of environmental contaminants and the adverse social determinants of health that put minority communities at increased risk for disease and mortality. The key categories of social determinants of health that contribute to racial and ethnic disparities in COVID-19 include neighborhood and physical environment, health and healthcare, occupation and job conditions, income and wealth, and education. Discrimination, including racism and associated chronic stress, influences each of these key critical topic areas (CDC, 2021d). This paper aims to critically examine how 
environmental racism aggravates the COVID-19 pandemic in the United States of America (USA) due to racial and ethnic disparities in exposure to environmental pollutants.

\section{Social Determinants of Health}

Social determinants of health are described as "the conditions in which people are born, grow, live, work and age" (WHO, 2018a). These conditions include biology, individual behavior, socioeconomic status, physical and social environment, racism, discrimination, health services, literacy levels, and legislative policies (Healthy People, 2020). Social determinants of health are primarily responsible for health inequities, or avoidable and unfair differences in health status between countries and between different groups of people within the same country (WHO, 2013, 2018b). Reducing health inequities is imperative because health is a fundamental human right, and failure to overcome inequities results in health disparities (WHO, 2018a). Health inequities are gaining increasing national and international attention due to only few countries being able to systematically reduce them (WHO, 2013). Various social, economic, political, environmental, and health system factors interact to play a central role in the social determinants of health and health inequities, with an ultimate impact on health equity and well-being (WHO, 2013). Human rights and the environment are interwoven, and the right to a healthy environment is endorsed in over 100 constitutions (United Nations, n.d.). Moreover, the recognized risk factors for COVID-19 complications need to be examined within the context of the social determinants of health, such as environmental racism, that put minority communities at increased risk for disease and mortality.

\section{Definitions}

Environmental racism can be described as "any practice, policy, or directive that differentially affects or disadvantages (whether intended or unintended) individuals, groups, or communities based on race or color" (Bullard, 1993: 23). Environmental racism can manifest itself as racial discrimination in environmental policymaking, enforcement of regulation and laws, the deliberate targeting of communities of color for toxic waste disposal and siting of polluting industries, the official sanctioning of lifethreatening poisons and pollutants in communities of color, and the history of excluding people of color from mainstream environmental groups, decision-making boards, commissions, and regulatory bodies (Chavis Jr., 1993). The main culprits of environmental racism include ignorance and indifference, insufficient testing of industrial chemicals, racism, housing and work discrimination, corporate greed, and negligent legislation (Washington, 2020a). Environmental equity can imply an equal sharing of environmental risk burdens and effects of environmental degradation (Cutter, 1995). Environmental justice denotes remedial action to rectify an injustice imposed on a specific group of people, mostly people of color in the USA (Bullard, 1994). It can be achieved through development, implementation, and enforcement of environmental laws; regulations; and policies to ensure everyone receives equal protection from environmental and health hazards and similar access to the decision-making process for a healthy environment (Environmental Protection Agency, n.d.). There is a need to carefully examine environmental racism and how systems create and perpetuate inequalities in exposure to environmental pollutants are fueling the COVID-19 pandemic.

\section{CHALLENGES}

\section{Housing}

Environmental racism can be reflected in housing discrimination which perpetuates inequalities in exposure to environmental pollutants (Washington, 2020a). Social distancing at home can be difficult when biased credit and mortgaging practices such as redlining reduce the likelihood that racial and ethnic minorities will own their own home. Resultantly, people of color may be relegated to apartment life, which poses challenges against social distancing when one must share crowded living spaces, corridors, and elevators (Washington, 2020b).

Furthermore, the COVID-19 pandemic has exacerbated the long history of housing instability for people of color in the USA due to widespread discrimination and racially targeted polices (Lake, 2020). Even before the COVID-19 pandemic began, Black and Latinx people experienced higher poverty rates than whites (Semega et al., 2019), and Black, Latinx, and Native American renters were more likely to be extremely low income (Aurand et al., 2020a) compared to whites. Communities of color are affected by housing insecurity in many ways. Renters of color often face racially targeted policies and practices when obtaining and maintaining housing, are more cost-burdened, and face higher rates of eviction compared to white renters (Lake, 2020). Eviction is stressful life event that can have lasting negative health impacts and fuel cycles of multigenerational poverty (Lundberg and Donnelly, 2019). Additionally, U.S. housing is not constructed to meet the needs of multigenerational families of color. Latinx, Native American, and Asian individuals, who increasingly live in multigenerational households, disproportionately live in overcrowded rental units that lack space and structure for larger households (Aurand et al., 2020; Cohn and Passel, 2018). Communities of color disproportionately experience homelessness (40\% identify as Black and $22 \%$ as Latinx), with worsening impacts expected during a pandemic (National Law Center on Homelessness \& Poverty, 2020).

Moreover, living conditions may increase exposure to COVID-19 among Hispanic families. A quarter of Hispanic people live in multigenerational families (compared to $15 \%$ of non-Hispanic whites), which may hinder efforts to socially distance or self-isolate when sick, if household space is limited (CDC, 2020d; Cohn and Passel, 2018). Social determinants of health encompass one's neighborhood and built environment, which includes access to transportation (CDC, 2020d). Black workers are more likely to rely on public transportation to commute to work, and one study found that public transportation contributes to racial disparities in COVID-19 deaths (McLaren, 2020). Overall, communities of color are especially vulnerable to COVID-19 due to various factors including differential exposure to housing discrimination and environmental contaminants. 


\section{Working Conditions}

The disparate racial impact of COVID-19 also manifests itself in working conditions. Patterns of racism and discrimination lead to Black persons being more likely to be exposed to the virus through work, and less likely to have access to high-quality health care and the resources like health insurance to maintain their health. As a result of racial discrimination in the labor market, Blacks are more likely to be overrepresented in jobs that cannot be done from home, paid less, terminated, unemployed longer, and to have their unemployment claims denied, compared to their white peers (Liu, 2020). Effects of the pandemic on Black workers include devastating job losses, spiking unemployment rates, and increased likelihood to be in front-line jobs as essential workers (Gould and Wilson, 2020).

Other considerations include that Black and Hispanic/Latinx workers are less likely to be able to work from home during the COVID-19 crisis, risking their health (Gould and Shierholz, 2020). For instance, many Hispanic people work in frontline jobs in food delivery, grocery stores, cleaning and sanitation services, and waste management, putting them at constant exposure to and risk of becoming infected with COVID-19 (Bucknor, 2016). Many women of color are also essential workers on the frontlines of the COVID-19 pandemic, which may lead to increased risks of contracting COVID-19 (Frye, 2020). Other barriers to accessing care include not having health insurance through work, which can create prohibitive medical costs for uninsured individuals. Amplified COVID-19 transmission risk among Black and Hispanic/Latinx workers is also related to inadequate provision of personal protective equipment (PPE), paid sick leave, hazard pay (i.e., additional compensation for working under hazardous condition), cleaning materials, and appropriate staffing levels (McClure et al., 2020). Therefore, racial, inequities in workplace conditions make racial and ethnic minorities especially vulnerable to COVID-19 exposure.

\section{Food}

With evidence linking obesity and obesity-related diseases to severe COVID-19 outcomes, it is important to recognize how persistent disparities in nutrition and obesity play a key role in the health inequities highlighted during this pandemic (Belanger et al., 2020). Disparities in nutrition are driven by the socioeconomic, environmental, and educational disadvantages that have historically afflicted vulnerable communities and that continue today. For example, while food insecurity affects about $11 \%$ of U.S. households, it is more common in Black, Latinx, and Native American households (U.S. Department of Agriculture, n.d.). People who experience food insecurity and live in food deserts (i.e., neighborhoods that lack grocery stores and other merchants of fresh produce) are at greater risk for obesity. Furthermore, Black (49.6\%), Native American (48.1\%), and Latinx (44.8\%) adults are disproportionately affected by obesity compared to the U.S adult (42\%) population (Belanger et al., 2020).

Poor access to nutritious food complicates health disparities. Food deserts are often full of vendors that sell junk food, tobacco, and alcohol. This influences obesity and nutritional deficiencies, which intensify the harms of environmental pollution. In another example of how exposure to environmental toxins affect disease risk, iron, Vitamin C, and calcium in the diet prevent the absorption of lead, a poisonous metal. A similar assertion can be made about access to exercise facilities and green spaces, which can protect against obesity (Washington, 2020a). Ultimately, the health disparities in nutrition and obesity associate closely with the disturbing racial and ethnic disparities related to COVID-19 (Belanger et al., 2020).

\section{Air}

Exposure to high levels of air pollution can cause serious health effects including respiratory diseases such as asthma, emphysema, COPD, and chronic bronchitis, cardiovascular problems, and cancer (National Institute of Environmental Health and Sciences, n.d.). The fact that communities of color are more exposed to polluted air is not a coincidence and is another example of environmental racism. Black and ethnic minority populations are more likely to live in neighborhoods where they are exposed to high levels of air pollution (Wu et al, 2020). Greater exposure to air pollution can aggravate heart diseases, trigger hypertension, compromise immune systems, and has been linked to shortened life expectancy (Washington, 2020a).

Residents of underserved communities often have the worst air quality due to bearing the burden of inequitable exposure to air population (Richmond, 2014). A prominent example is the stretch of the Mississippi River between New Orleans and Baton Rouge dubbed "Cancer Alley" because of its concentration of oil refineries and petrochemical facilities. One of the most notoriously polluted areas in the country, the surrounding communities are predominantly Black and of lowincome (Pasley, 2020). Area residents are 50 times more likely to get cancer than the average American and area counties have reported some of the highest COVID-19 death rates in the USA (Younes and Sneath, 2020). In another example, toxic waste and air pollution and have been associated with higher rates of diabetes for Blacks (Ruiz et al., 2018). Moreover, air pollution is exacerbated by climate change, which worsens COVID-19 illness. People residing in areas with poor air quality suffer more COVID-19 complications, including longer hospital stays due to respiratory or cardiovascular problems that are worsened by environmental factors (Watts et al., 2020). Residents of low-income in redlined neighborhoods that lack tree cover and greenery are also disproportionately vulnerable to extreme weather events that increase risk for illnesses such as heat stroke (Salas, Shultz, and Solomon, 2020; Watts et al., 2020). In this age of COVID-19, there needs to be greater scrutiny into environmental racism as a precursor to disparate air pollution exposure and a determinant of preexisting health conditions.

\section{Water}

Higher lead levels have been reported among Black children compared to white children, with the burden of higher lead exposure starting before birth and persisting into early childhood (Cassidy-Bushrow et al., 2017). Events such as the Flint water crisis reveal a harsh reality that lead is one of many toxic legacies in U.S. cities, which include segregation, redlining, and exclusion. During this tragedy in Flint, Michigan (a city that is over $50 \%$ Black and in which over $40 \%$ of 
residents live below the federal poverty line), over 100,000 residents were potentially exposed to high levels of lead in the drinking water (Clark, 2018; World Population Review, 2020). Lead is a cumulative toxicant that affects multiple body systems. Young children are especially vulnerable and there is no safe level of exposure. Lead exposure contributes to the global burden of heart disease, stroke, and developmental intellectual disability (WHO, 2019). The aforementioned health conditions also put people at higher risk for COVID-19.

The Flint water crisis illustrates persisting segregation even half a century after the civil rights era, and a stark reminder that race is often the best predictor for exposure to pollutants (Clark, 2018). Poor governmental response to the Flint water crisis is an example of systematic racism that goes back decades and is at the center of problems that caused a lead-contaminated water crisis in the majority Black city of Flint, Michigan. In addition, a state-established body, the Michigan Civil Rights Commission, determined that the poor governmental response to the Flint crisis was a result of systemic racism (Denchak, 2018). Moreover, Flint is located in Genesee County, which has among the highest known COVID19 deaths in the state of Michigan (USA Facts, 2021).

\section{Soil}

Racial disparities in lead toxicity are also due to disparate exposure to lead-contaminated soil. Black and Hispanic neighborhoods in the USA disproportionately contain environmental toxins that have accumulated in the soil due to historical pollution from congested highways, industries, and manufacturing plants; there has also been differential cleanup of contaminated soil surrounding formerly toxic plants (Sampson and Winter, 2016). Blacks and Hispanics are also disproportionately exposed to older housing with deteriorating lead-based paint and to neighborhoods containing dilapidated housing structures that contribute lead to the soil (Lanphear et al, 1998; Sampson and Winter, 2016). Furthermore, Black and Latinx children are at higher risk of lead exposure compared to children in other racial and ethnic groups (Aelion et al., 2013). The disparate emissions of multiple contaminants into the soil aggravates COVID-19 risk among racial and ethnic minorities.

\section{Psychosocial Stressors (Police Brutality)}

Black Americans have been disproportionately affected by police brutality before and during the COVID-19 pandemic. COVID-19 along with international anti-racism protests against police brutality has brought the discussion of environmental racism to the forefront as a systematic injustice that people of color face (Yaghoobi et al., 2020). Subjection to crowd control tactics like tear gas during protests against police brutality, mass incarceration of Blacks due to aggressive enforcement of low-level offenses, and increase in chronic stress caused by persistent police-related trauma can hinder social distancing and exaggerate risk for COVID-19 infection (Njoku, Ahmed, and Bolaji, 2020). Discrimination can obstruct healthy behaviors if Black persons fear raising police's suspicions for wearing a mask or having the police called on them for not wearing one (Rouhandeh, 2020). Perception of COVID-associated discrimination has been associated with race/ethnicity and wearing masks, with preliminary data showing that Blacks are disproportionately arrested for social distancing violations (Kaplan and Hardy, 2020; Liu et al., 2020). Such psychosocial factors increase the probability of exposure to the stressor of police presence, incarceration, and potentially deadly encounters (Rouhandeh, 2020).

Furthermore, incarceration in the family can play a huge role in affecting minority women's life during a pandemic. Issues related to the social environment can have important maternal and child health considerations such as availability of sufficient social support during pregnancy and delivery and can impact minority populations more during the COVID-19 pandemic (Dongarwar et al., 2020).

\section{DISCUSSION}

Strategies are needed to combat the legacy of environmental racism that elevates disease risk among racial and ethnic minorities already susceptible to COVID-19. The expansion and continuation of policies, programs, community engagement initiatives, education, and funding are necessitated to promote environmental health equity.

\section{Improved Policies}

Continued polices are needed to promote safe and healthy workplaces. Government policies are needed to provide safe environments, adequate PPE, paid sick leave, and COVID-19 testing among workers (McClure et al., 2020). Recently enacted federal legislation, the Families First Coronavirus Response Act, has required all public agencies and some private firms to provide paid sick leave during this public health crisis. This law excludes employees at businesses with over 500 employees, therefore not reaching all uninsured workers (Tolbert, 2020). Expansion of such polices are needed.

Immediate and long-terms solutions are needed at the local, state, and federal levels to address housing discrimination and the affordable housing crisis. This can be done by extending protections for renters against the threat of eviction, repealing additional barriers to obtaining temporary and long-term housing, and increasing the provision of affordable, accessible housing that meets families' needs (Lake, 2020). Examples of barriers include having an eviction on one's credit report or public record (Lake, 2020).

There is an urgent need for public health policies and legislation that reduce food insecurity and food deserts in vulnerable communities so as to address the underlying social determinants of health (Belanger et al., 2020). Additionally, local zoning codes and land use policies have historically been methods for segregating people and concentrating pollution in communities of color. Since state and federal environmental laws and regulations are fundamentally limited in addressing local placement of pollution burdens, local polices for environmental justice are critical to ensuring that all people are free from unequal and cumulative exposure to environmental burdens (Batista, 2019).

\section{Comprehensive National Programs}

Programs and policies are needed to improve access to COVID-19 testing, diagnosis, and medical treatment among vulnerable populations, particularly among uninsured 
individuals and people of color. Policy options and action opportunities to close the health equity gap include working towards universal healthcare coverage with special attention to social and cultural barriers. This can be achieved by expanding the availability of comprehensive primary and secondary services, which address the multiple determinants of health in minority communities. Such efforts can help improve coordination between levels of care. Strategies should be tested and evaluated to extend access to and ensure quality care for minority communities, with provisions that stigmatization and inequities are not reinforced (WHO, 2013). Moreover, developing comprehensive national programs to provide integrated health care to the underinsured and uninsured impacted by COVID-19 would promote increased resiliency within these communities and reduce their susceptibility to adverse outcomes and long-term socioeconomic hardships (Novacek et al., 2020).

\section{Community Partnerships, Advocacy, and Engagement}

Other strategies to address the impacts of environmental racism and close the health equity gap include promoting ongoing engagement among multiple sectors to institutionalize health equity goals. Also needed is ongoing data collection that measures racial inequities in health to provide the foundation for political action and accountability on the determinants of health and the advancement of health equity (WHO, 2013). Attention to the cumulative effects of exposures to environmental contaminants in the context of social stressors, political forces, and policy decisions influencing health can guide implementation of sustainable approaches while also enhancing environmental health literacy of the community. When researchers engage affected community members, residents can feel empowered rather than discouraged and disenfranchised (Yaghoobi et al., 2020).

Community engaged advocacy between the Black community and law enforcement during the pandemic and beyond will be needed to address the disproportionate impact of police brutality among the Black community (Njoku et al., 2020). Thus, there is a need to strengthen provider-client relationships and help community residents feel more connected, comfortable, and empowered while obtaining health and human services.

Communities of color experience increased underlying health conditions because they reside in more polluted communities than the privileged. As a result, researchers must build genuine community connections due to decades of educational disparities that have led to stark underrepresentation of racial and ethnic minority groups in the environmental health research community (Yaghoobi, Khemet Taiwo, and Lein, 2020). Therefore, solutions are needed to enhance community engagement among stakeholders of racial and ethnic health.

\section{Education and Enhanced Curriculum}

Addressing environmental health disparities will require a multifaceted approach from diverse stakeholders, including academic institutions. Being amidst a global pandemic emphasizes the crucial role of public health in responding to the COVID-19 outbreak. COVID-19 racial and ethnic disparities necessitate the expansion and continuation of higher education public health curriculum to promote environmental health equity.

Health disparities curriculum is important to promote student awareness about health disparities and prepare an engaged, motivated future workforce (Njoku, 2018). Embedding issues of environmental justice in primary school curriculum can help improve environmental literacy and promote health equity (Nussbaum, 2013; Washington and Strong, 1997). Curriculum can be expanded to teach about the environmental determinants of health that contribute to racial and ethnic disparities in COVID-19 outcomes. Developing online health disparities courses can increase the reach of such curricula (Njoku, 2019).

Furthermore, while there is an increasing number of Public Health programs in the USA (CEPH, 2020a), a review of overall MPH curriculum design trends revealed that about $11 \%$ of curricula contained a single concentration program in Health Equity or Priority Populations (CEPH, 2020b). This suggests an opportunity to incorporate environmental health equity content into public health curriculum.

\section{Increased Funding}

Increased population and public health funding are needed to promote environmental health equity among vulnerable populations. COVID-19 recovery must include provisions for environmental justice grants to address the disproportionate impact of COVID-19 on communities of color and of low income (Bergstrom, 2020). Continued federal investment in community development programs is needed to ensure an equitable, healthy, and climate change-ready economic recovery from the COVID-19 pandemic (Kelly and Reta, 2020).

Strategies to achieve these goals include making equity, racial justice, and a just economy core goals of city resilience and climate action plans; expanding economic opportunities and the availability of affordable housing; and ensuring access to affordable and clean transportation (Kelly, Martinez, and Hathaway-Williams, 2017). Additional considerations for supporting just and climate-resilient community development include expanding funding for federally qualified health centers, providing federal funding for environmental justice grant programs, and allotting funding to support antidisplacement strategies (Kelly and Reta, 2020).

\section{CONCLUSION}

In conclusion, the global COVID-19 pandemic has revealed significant racial and ethnic inequities in COVID-19 outcomes. There is a need to investigate how environmental racism intensifies the COVID-19 pandemic and reveals racial inequities in exposure to environmental pollutants. Moreover, the established risk factors for COVID-19 complications need to be examined within the context of the social determinants of health, such as environmental racism, that place U.S. communities of color at increased risk for disease and mortality. These determinants include unequal exposure to environmental pollutants in housing, workplaces, food, air, water, and soil, hazardous waste, and the global environmental climate. Psychosocial factors stressors in the 
physical environment such as exposure to police brutality also determine health.

Strategies are needed to tackle the legacy of environmental racism that aggravates disease risk among racial and ethnic minorities already susceptible to COVID-19. Recommendations include expanding and continuing policies, programs, community engagement efforts, education, and funding to promote environmental health equity. These efforts may help mitigate the negative effects of disparate exposure to environmental contaminants among communities of color in the USA. It is incumbent that the fight for environmental justice be at the center of COVID-19 recovery.

Funding: The author received no financial support for the research, authorship, and/or publication of this article.

Declaration of interest: The author reports no potential conflict of interest relevant to this article.

Ethics approval and consent to participate: Not applicable.

Availability of data and materials: All data generated or analyzed during this study are available for sharing when appropriate request is directed to the author.

\section{REFERENCES}

Aelion, C. M., Davis, H. T., Lawson, A. B., Cai, B. and McDermott, S. (2013). Associations between soil lead concentrations and populations by race/ethnicity and income-to-poverty ratio in urban and rural areas. Environmental Geochemistry and Health, 35(1), 1-12.

Ameh, G. G., Njoku, A., Inungu, J. and Younis, M. (2020). Rural America and Coronavirus Epidemic: Challenges and solutions. European Journal of Environment and Public Health, 4(2), em0040. https://doi.org/10.29333/ejeph/8200

Aurand A., Emmanuel, D., Threet, D., Rafi, I. and Yentel, D. (2021). The Gap: A shortage of affordable homes. Washington: National Low Income Housing Coalition. Available at: https://reports.nlihc.org/sites/default/files/ gap/Gap-Report_2021.pdf (Accessed: 20 May 2021).

Aurand A., Emmanuel, D., Threet, D., Rafi, I. and Yentel, D. (2020). Out of reach: The high cost of housing. Washington: National Low Income Housing Coalition. Available at: https://reports.nlihc.org/sites/default/files/ oor/OOR_2020.pdf (Accessed: 27 May 2021).

Batista, A. (2019). Local policies for environmental justice: A national scan. Available at: https://www.nrdc.org/sites/ default/files/local-policies-environmental-justicenational-scan-tishman-201902.pdf (Accessed: 27 May 2021).

Belanger, M. J., Hill, M. A., Angelidi, A. M., Dalamaga, M., Sowers, J. R. and Mantzoros, C. S. (2020). Covid-19 and disparities in nutrition and obesity. New England Journal of Medicine, 383(11), e69. https://doi.org/10.1056/NEJMp20 21264

Bergstrom, C. (2020). COVID-19 recovery must include environmental justice. Available at: https://thebridge.agu. org/2020/08/21/covid-19-recovery-must-includeenvironmental-justice/ (Accessed: 27 May 2021).
Bucknor, C. (2016). Hispanic workers in the United States (No. 2016-19). Center for Economic and Policy Research (CEPR). Available at: https://cepr.net/images/stories/reports/hispa nic-workers-2016-11.pdf (Accessed: 27 May 2021).

Bullard, R. (1993). The threat of environmental racism. Natural Resources \& Environment, 7(3), 23-56. Available at: http://www.jstor.org/stable/40923229 (Accessed: 27 May 2021).

Bullard, R. D. (1994). Overcoming racism in environmental decision making. Environment: Science and Policy for Sustainable Development, 36(4), 10-44. https://doi.org/ 10.1080/00139157.1994.9929997

Cassidy-Bushrow, A. E., Sitarik, A. R., Havstad, S., Park, S. K., Bielak, L. F., Austin, C., Johnson, C. C. and Arora, M. (2017). Burden of higher lead exposure in African Americans starts in utero and persists into childhood. Environment International, 108, 221-227. https://doi.org/10.1016/ j.envint.2017.08.021

Centers for Disease Control and Prevention. (2021a, March 8). How to protect yourself and others. Available at: https:/www.cdc.gov/coronavirus/2019-ncov/preventgetting-sick/prevention.html (Accessed: 27 May 2021).

Centers for Disease Control and Prevention. (2021b, May 13). People with certain medical conditions. Available at: https://www.cdc.gov/coronavirus/2019-ncov/need-extraprecautions/groups-at-higher-risk.html (Accessed: 27 May 2021).

Centers for Disease Control and Prevention. (2021c, May 26). COVID-19 Hospitalization and Death by Race/Ethnicity. Available at: https://www.cdc.gov/coronavirus/2019ncov/covid-data/investigations-discovery/hospitalizationdeath-by-race-ethnicity.html (Accessed: 27 May 2021).

Centers for Disease Control and Prevention. (2021d, April 19). Health equity considerations and racial and ethnic minority groups. Available at: https:/www.cdc.gov/coronavirus/ 2019-ncov/community/health-equity/race-ethnicity.html ?CDC_AA_refVal=https\%3A\%2F\%2Fwww.cdc.gov\%2Fcoro navirus\%2F2019-ncov\%2Fneed-extra-precautions\%2Fraci al-ethnic-minorities.html (Accessed: 27 May 2021).

Chavis Jr, B. F. (1993). 'Foreword', in Bullard, R. (ed.) Confronting environmental racism: Voice from the grassroots. Boston: South End Press, p. 3.

Clark, A. (2018). The poisoned city: Flint's water and the American urban tragedy. Metropolitan Books.

Cohn, D. V. and Passel, J. S. (2018). Record 64 million Americans live in multigenerational households. Washington, DC: Pew Research Center. https://www.pewresearch.org/facttank/2018/04/05/a-record-64-million-americans-live-inmultigenerational-households/ (Accessed: 27 May 2021).

Council on Education for Public Health. (2020). CEPH trends 2020. Available at: https://ceph.org/trends2020/ (Accessed: 27 May 2021).

Council on Education for Public Health. (2020). CEPH trends 2020. MPH curriculum. Available at: https://media.ceph.org /documents/MPH_Curriculum_Design.pdf (Accessed: 27 May 2021). 
Cutter, S. L. (1995). Race, class, and environmental justice. Progress in Human Geography, 19(1), 111-122. https://doi.org/10.1177/030913259501900111

Denchak, M. (2018). Flint water crisis: Everything you need to know. National Resource Defense Council. Available at: https://www.nrdc.org/stories/flint-water-crisiseverything-you-need-know (Accessed: 27 May 2021).

Dongarwar, D., Ajewole, V. B., Oduguwa, E., Ngujede, A., Harris, K., Ofili, T. U., Olaleye, O. A. and Salihu, H. M. (2020). Role of Social Determinants of Health in Widening Maternal and Child Health Disparities in the Era of Covid19 Pandemic. International journal of MCH and AIDS, 9(3), 316-319. https://doi.org/10.21106/ijma.398

Egede, L. E., \& Walker, R. J. (2020). Structural racism, social risk factors, and Covid-19-A dangerous convergence for Black Americans. New England Journal of Medicine, 383(12), e77. https://doi.org/10.1056/NEJMp2023616

Environmental Protection Agency. (n.d.). Environmental justice. Available at: https:/www.epa.gov/environmentaljustice (Accessed: 27 May 2021).

Frye, J. (2020, April 23). On the frontlines at work and at home: The Disproportionate economic effects of the Coronavirus pandemic on women of color. Available at: https://www. americanprogress.org/issues/women/reports/2020/04/23/4 83846/frontlines-work-home/ (Accessed: 27 May 2021).

Gould, E. and Shierholz, H. (2020, March 19). Not everybody can work from home: Black and Hispanic workers are much less likely to be able to telework. Available at: https://www.epi. org/blog/black-and-hispanic-workers-are-much-lesslikely-to-be-able-to-work-from-home/ (Accessed: 27 May 2021).

Gould, E. and Wilson, V. (2020, June 1). Black workers face two of the most lethal preexisting conditions for coronavirusracism and economic inequality. Available at: https://www.epi.org/publication/black-workers-covid/ (Accessed: 27 May 2021).

Hooper, M. W., Nápoles, A. M., \& Pérez-Stable, E. J. (2020). COVID-19 and Racial/Ethnic Disparities. JAMA, 323(24), 2466-2467. https://doi.org/10.1001/jama.2020.8598

Kaplan, J. and Hardy, B. (2020, May 8). Early data shows Black people are being disproportionally arrested for social distancing violations. Available at: https:/www.pro publica.org/article/in-some-of-ohios-most-populousareas-black-people-were-at-least-4-times-as-likely-tobe-charged-with-stay-at-home-violations-as-whites (Accessed: 27 May 2021).

Kelly, C. and Reta, M. (2020, October 8). Building equitable, healthy, and climate change-ready communities in the wake of COVID-19. Available at: https://www.american progress.org/issues/green/reports/2020/10/08/491371/buil ding-equitable-healthy-climate-change-readycommunities-wake-covid-19/ (Accessed: 27 May 2021).

Kelly, C., Martinez, C. and Hathaway-Williams, W. (2017, September 28). A framework for local action on climate change. Available at: https://www.americanprogress.org/ issues/green/reports/2017/09/28/439712/frameworklocal-action-climate-change/ (Accessed: 27 May 2021).
Lake, J. (2020, October 30). The pandemic has exacerbated housing instability for renters of color. Available at: https://www.americanprogress.org/issues/poverty/reports /2020/10/30/492606/pandemic-exacerbated-housinginstability-renters-color/ (Accessed: 27 May 2021).

Lanphear, B. P., Byrd, R. S., Auinger, P. and Schaffer, S. J. (1998). Community characteristics associated with elevated blood lead levels in children. Pediatrics, 101(2), 264-271. https://doi.org/10.1542/peds.101.2.264

Liu, Y., Finch, B. K., Brenneke, S. G., Thomas, K. and Le, P. D. (2020). Perceived discrimination and mental distress amid the COVID-19 pandemic: Evidence from the Understanding America Study. American Journal of Preventive Medicine, 59(4), 481-492. https://doi.org/10.1016/j.amepre.2020.06.007

Lundberg, I. and Donnelly, L. (2019). A Research note on the prevalence of housing eviction among children Born in U.S Cities. Demography, 56(1), 391-404. https://doi.org/ 10.1007/s13524-018-0735-y

McClure, E. S., Vasudevan, P., Bailey, Z., Patel, S. and Robinson, W. R. (2020). Racial capitalism within public health-how occupational settings drive COVID-19 disparities. American journal of epidemiology, 189(11), 1244-1253. https://doi.org/10.1093/aje/kwaa126

McLaren, J. (2020). Racial Disparity in COVID-19 Deaths: Seeking Economic Roots with Census data (No. w27407). National Bureau of Economic Research. https://doi.org/10.3386/w27407

National Homelessness Law Center. (2020). Racism, homelessness, and COVID-19. Available at: https://nlchp.org/wp-content/uploads/2020/05/RacismHomelessness-and-COVID-19-Fact-Sheet-_Final_2.pdf (Accessed: 27 May 2021).

National Institute of Environmental Health and Sciences. (n.d.). Air Pollution and Your Health. Available at: https://www.niehs.nih.gov/health/topics/agents/airpollution/index.cfm (Accessed: 27 May 2021).

Njoku, A. (2018). Teaching health disparities awareness in undergraduate public health courses. International Journal for the Scholarship of Teaching and Learning, 12(2): Article 15. https://doi.org/10.20429/ijsotl.2018.120215

Njoku, A. (2019). Effect of online courses on US college students' knowledge about health disparities. Health Education Journal, 78(5), 510-523. https://doi.org/10.1177/ 0017896918823226

Njoku, A., Ahmed, Y. and Bolaji, B. (2020). Police brutality against Blacks in the United States and ensuing protests: Implications for social distancing and Black health during COVID-19. Journal of Human Behavior in the Social Environment, 1-9. https://doi.org/10.1080/10911359.2020. 1822251

Novacek, D. M., Hampton-Anderson, J. N., Ebor, M. T., Loeb, T. B. and Wyatt, G. E. (2020). Mental health ramifications of the COVID-19 pandemic for Black Americans: Clinical and research recommendations. Psychological Trauma: Theory, Research, Practice, and Policy. https://doi.org/10.1037/tra0000796 
Nussbaum, M. M. (2013). Embedding issues of environmental justice in the mainstream curriculum. Environmental Justice, 6(1), 34-40. https://doi.org/10.1089/env.2012.0038

Pasley, J. (2020, April 9). Inside Louisiana’s horrifying 'Cancer Alley,' an 85-mile stretch of pollution and environmental racism that's now dealing with some of the highest coronavirus death rates in the country. Available at: https://www.businessinsider.com/louisiana-cancer-alleyphotos-oil-refineries-chemicals-pollution-2019-11 (Accessed: 27 May 2021).

Richmond, M. E. (2014). Protection of underserved communities from adverse effects of air pollution: Is the present federal regulatory system effective? Race, Gender \& Class, 7-18. https://www.jstor.org/stable/43496955

Rouhandeh, A. (2020, June 21). Social distancing, racism, and protecting people in a pandemic without the police. Available at: https://prospect.org/coronavirus/socialdistancing-racism-protecting-people-without-police/ (Accessed: 27 May 2021).

Ruiz, D., Becerra, M., Jagai, J. S., Ard, K. and Sargis, R. M. (2018). Disparities in environmental exposures to endocrine-disrupting chemicals and diabetes risk in vulnerable populations. Diabetes Care, 41(1), 193-205. https://doi.org/10.2337/dc16-2765

Salas, R. N., Shultz, J. M. and Solomon, C. G. (2020). The climate crisis and COVID-19-a major threat to the pandemic response. New England Journal of Medicine, 383(11), e70. https://doi.org/10.1056/NEJMp2022011

Sampson, R. J. and Winter, A. S. (2016). The racial ecology of lead poisoning: Toxic inequality in Chicago neighborhoods, 1995-2013. Du Bois Review: Social Science Research on Race, 13(2), 261-283. https://doi.org/10.1017/ S1742058X16000151

Semega, J., Kollar, M., Shrider, E.A. and and Creame, J.F. (2020). Income and Poverty in the United States: 2019. Washington: U.S. Census Bureau. Available at: https://www.census.gov/content/dam/Census/library/publ ications/2020/demo/p60-270.pdf (Accessed: 27 May 2021).

Sohrabi, C., Alsafi, Z., O’Neill, N., Khan, M., Kerwan, A., AlJabir, A., Iosifidis, C. and Agha, R. (2020). World Health Organization declares global emergency: A review of the 2019 Novel Coronavirus (COVID-19). International Journal of Surgery (London, England), 76, 71-76. https://doi.org/10.1016/j.ijsu.2020.02.034

Solar, O. and Irwin, A. (2010). A conceptual framework for action on the social determinants of health. WHO Document Production Services. Available at: https://www. who.int/sdhconference/resources/Conceptualframeworkfo ractiononSDH_eng.pdf . (Accessed: 27 May 2021).

Tolbert, J (2020). What issues will uninsured people face with testing and treatment for COVID-19? The Henry J. Kaiser Family Foundation. Available at: https://www.kff.org/ uninsured/fact-sheet/what-issues-will-uninsured-peopleface-with-testing-and-treatment-for-covid-19/ (Accessed: 27 May 2021).
U.S. Department of Agriculture. (n.d.). Food security in the U.S. Available at: https://www.ers.usda.gov/topics/foodnutrition-assistance/food-security-in-the-us/keystatistics-graphics.aspx (Accessed: 27 May 2021).

U.S. Department of Health and Human Services. (2020). Social determinants of health. Available at: https://www. healthypeople.gov/2020/topics-objectives/topic/socialdeterminants-of-health (Accessed: 27 May 2021).

United Nations. (n.d.). What are environmental rights? Available at: https://www.unenvironment.org/exploretopics/environmental-rights-and-governance/what-wedo/advancing-environmental-rights/what (Accessed: 27 May 2021).

USA Facts. (2021, May 26). Michigan Coronavirus Cases and Deaths. Available at: https://usafacts.org/visualizations/ coronavirus-covid-19-spread-map/state/michigan (Accessed: 27 May 2021).

Washington, H. A. (2020a). How environmental racism is fuelling the coronavirus pandemic. Nature, 241-241. https://doi.org/10.1038/d41586-020-01453-y

Washington, H. A. (2020b). Healing a Poisoned World. Available at: https://www.aft.org/hc/fall2020/washington (Accessed: 27 May 2021).

Washington, R. O. and Strong, D. (1997). A model for teaching environmental justice in a planning curriculum. Journal of Planning Education and Research, 16(4), 280-290. https://doi.org/10.1177/0739456X9701600404

Watts, N., Amann, M., Arnell, N., Ayeb-Karlsson, S., Beagley, J., Belesova, K., ... and Costello, A. (2020). The 2020 report of The Lancet Countdown on health and climate change: responding to converging crises. The Lancet. https://doi.org/10.1016/S0140-6736(20)32290-X

World Health Organization. (2013). Closing the health equity gap: Policy options and opportunities for action. Available at: https://apps.who.int/iris/bitstream/handle/10665/7833 5/9789241505178_eng.pdf;jsessionid=85C111FD861E0276 0C27FC65BD24BDCF? sequence=1 (Accessed: 27 May 2021).

World Health Organization. (2018a). Social determinants of health. Available at: http://www.who.int/social_determi nants/sdh_definition/en/ (Accessed: 27 May 2021).

World Health Organization. (2018b). Equity. Available at: http://www.who.int/healthsystems/topics/equity/en/ (Accessed: 27 May 2021).

World Health Organization. (2019, August 23). Lead poisoning and health. Available at: https://www.who.int/newsroom/fact-sheets/detail/lead-poisoning-and-health (Accessed: 27 May 2021).

World Health Organization. (2021). Coronavirus disease (COVID-19) Weekly Epidemiological Update and Weekly Operational Update. Available at: https://www.who.int/ emergencies/diseases/novel-coronavirus-2019/situationreports (Accessed: 27 May 2021). 
Wu, X., Nethery, R. C., Sabath, M. B., Braun, D. and Dominici, F. (2020). Air pollution and COVID-19 mortality in the United States: Strengths and limitations of an ecological regression analysis. Science Advances, 6(45), eabd4049. https://doi.org/10.1126/sciadv.abd4049

Yaghoobi, B., Taiwo, T.K. and Lein, P. (2020, September 2). Going viral: COVID-19, environmental injustice \& institutionalised racism. Available at: https://www.openaccessgovernment.org/going-viralcovid-19-environmental-injustice-institutionalisedracism/93724/ (Accessed: 27 May 2021).
Younes, L. and Sneath, S. (2020, September 11). New research shows disproportionate rate of Coronavirus deaths in polluted areas. Available at: https://www.propublica.org/ article/new-research-shows-disproportionate-rate-ofcoronavirus-deaths-in-polluted-areas (Accessed: 27 May 2021).

Young, B. E., Ong, S., Kalimuddin, S., Low, J. G., et al. (2020). Epidemiologic features and clinical course of patients infected with SARS-CoV-2 in Singapore. JAMA, 323(15), 1488-1494. https://doi.org/10.1001/jama.2020.3204

Zhu, N., Zhang, D., Wang, W., Li, X., et al. (2020). A novel Coronavirus from patients with pneumonia in China, 2019. The New England Journal of Medicine, 382(8), 727-733. https://doi.org/10.1056/NEJMoa2001017 